\title{
A new experimental model to study preneoplastic lesions in achalasia of the esophagus ${ }^{1}$
}

\author{
Novo modelo experimental para o estudo de lesões preneoplásicas na \\ acalasia de esôfago
}

\author{
Marcelo Vinícius Oliveira Vespúcio², Ricardo Mesquita Paschoal 3 , Sérgio Zucoloto ${ }^{4}$, Fábio Rogério Brosci Garcia ${ }^{5}$, \\ Marcelo Belini Dalio $^{6}$, Edson Garcia Soares ${ }^{7}$, Sérgio Britto Garcia ${ }^{8}$ \\ 1. Master thesis presented to Ribeirão Preto School of Medicine (FMRP-USP), in Experimental Pathology Post-Graduation Program. \\ 2. Dentistry, Master of Experimental Pathology Post-Graduation Program FMRP-USP. \\ 3. Medical resident of FMRP-USP Clinical Hospital. \\ 4. Professor, Chairman of Pathology Department FMRP-USP. \\ 5. Medical resident of FMRP-USP Clinical Hospital. \\ 6. Medical resident of FMRP-USP Clinical Hospital. \\ 7. Doctor of Medicine. Full Professor of Pathology Department FMRP-USP. \\ 8. PhD of Medicine. Full Professor of Pathology Department FMRP-USP.
}

\section{ABSTRACT}

Purpose: Develop an experimental model to study esophageal preneoplastic lesions induced by diethylnitrosamine in rats with achalasia. Methods: Male Wistar rats were divided into four groups: control - C $(n=8)$; rats with megaesophagus - B $(n=8)$; rats treated with DEN - D ( $=15)$ and rats with megaesophagus plus DEN - BD ( $=15)$. Megaesophagus can be experimentally obtained in rats by topical application of benzalkonium choride. The morphology and PCNA labeling index of the epithelium were evaluated. Results: The morphometric analysis showed an increase in epithelial thickness in the animals of group BD $\left(2166 \pm 1012 \mathrm{~mm}^{2}\right)$ when compared to the other groups $\left(\mathrm{C}=878 \pm 278 \mathrm{~mm}^{2} ; \mathrm{B}=1746 \pm 144 \mathrm{~mm}^{2}\right.$ and $\mathrm{D}=$ $1691 \pm 697 \mathrm{~mm}^{2}$ ), mainly due to basal layer hyperplasia, besides an increase in the keratin of the superficial layer. The PCNA labeling index in the basal layer was significantly higher in the group $\mathrm{BD}(0,695 \pm 0,111)$ when compared to the other groups $(C=0,490 \pm 0,132 ; B=0,512 \pm 0,215$ and $D=0,477 \pm 0,198)$. Conclusions: Our data confirm in an experimental model the previous observation in humans of increased epithelial cell proliferation during the esophageal carcinogenic process in achalasia and may be useful to further studies on the mechanisms of the esophageal carcinogenesis and the the design of follow-up endoscopic studies for patients with achalasia.

Key words: Esophageal Achalasia. Animal experimentation. Rats.

\section{RESUMO}

Objetivo: Desenvolver um modelo experimental que permitisse o estudo de lesões preneoplásicas induzidas por diethylnitrosamina em ratos com acalasia. Métodos: Ratos Wistar machos foram distribuídos em quatro grupos: controle $C(n=8)$; ratos com megaesôfago - B $(n=8)$; ratos tratados com DEN - D ( $n=15)$ e ratos com megaesôfago mais DEN - BD $(n=15)$. O megaesôfago pode ser obtido experimentalmente através da aplicação tópica de cloreto de benzalcônio. Foi avaliada a morfologia do epitélio e a proliferação celular do epitélio pelo método do PCNA. Resultados: A análise morfométrica mostrou aumento da espessura epitelial no grupo BD $\left(2166 \pm 1012 \mathrm{~mm}^{2}\right)$ em relação aos outros grupos $\left(\mathrm{C}=878 \pm 278 \mathrm{~mm}^{2}\right.$; B $=1746 \pm 144 \mathrm{~mm}^{2}$ e $\mathrm{D}=1691 \pm 697 \mathrm{~mm}^{2}$ ), principalmente devido a uma hiperplasia da camada basal e um aumento na queratina da camada superficial. O índice de marcação pelo PCNA na camada basal foi significantemente maior neste mesmo grupo $(0,695 \pm 0,111)$ quando comparado com os outros (C-0,490 $\pm 0,132$; B-0,512 $\pm 0,215$ e D-0,477 $\pm 0,198)$. Conclusões: Estes dados confirmam através de um modelo experimental o aumento proliferativo celular durante o processo de carcinogênese na acalasia do esôfago e podem ser úteis durante estudos de endoscopia realizados em pacientes que possuem acalasia.

Descritores: Acalasia Esofágica. Experimentação animal. Ratos.

\section{Introduction}

Esophageal cancer (EC) remains a leading cause of cancer-related deaths in many parts of the world. The lack of early detection methods is the key factor for this high EC incidence and impairs the design of useful prevention strategies. Therefore, there is the need for animal models evaluating the mechanisms of esophageal carcinogenesis and investigating protective factors against this disease ${ }^{1}$. The literature has demonstrated a significant positive association between EC and achalasia, an impairement of esophageal peristalsis and of the opening of the lower esophageal $^{2}$. The prognosis of an "achalasia-carcinoma" is generally considered poor, although systematic studies assessing the incidence, prevalence, and prognosis for these patients are scarce ${ }^{3}$. The most common cause of 
achalasia is Chagas' disease which causes associated megaesophagus (ME). Several studies have shown the existence of a high frequency of association between $\mathrm{ME}$ and $\mathrm{EC}^{4}$. The reasons for this association have not been completely established. They are possibly related to food stasis and irritation of the mucous membrane ${ }^{5}$. The mechanisms of cancer development in ME are poorly known and their understanding is being jeopardized of the absence of adequate experimental models. We had previously shown that achalasia and ME can be experimentally obtained in rats by topical application of benzalkonium choride (BAC) to the abdominal portion of the esophagus and by ablation of the ganglion cells of the myenteric plexus ${ }^{6}$. It is well established in the literature that some nitro components, such as the diethylnitrosamine (DEN), can induce experimental carcinoma in the esophagus of rats ${ }^{7}$. Therefore, the purpose of the present experiment was to develop an experimental model combining achalasia with carcinogenesis of the esophagus and to allow the design of further studies for a more specific elucidation of mechanisms of association between these pathologies. PCNA is a nuclear protein synthesized in the late G1 and S phases of the cell cycle whose expression is associated with DNA synthesis and cell proliferation ${ }^{8}$. Therefore, PCNA expression has been generally utilized as a useful indicator to determine the biologic behavior of various lesions and the prognosis of malignant disease ${ }^{9}$. It has been previously reported that stasis esophagitis is associated with a significant increase in the thicknees of the basal layer of the mucosa ${ }^{5}$. This hyperplasia may be an intermediate condition explaining the higher frequency of cancer among patients with chagasic megaesophagus. Thus, in order to determine the proliferative responses of the esophageal mucosa in experimental achalasia associated with chemically-induced esophageal carcinogenesis, we performed an immunohistochemical study of PCNA and a morphometric study of the epithelium.

\section{Methods}

Male Wistar rats $(n=46)$ weighing about $50 \mathrm{~g}$ were anaesthetized with 50mg sodium thiopental (Abbott, Brazil) per kg body weight and laparotomized, and the abdominal portion of the esophagus was wrapped with a thick strip of gauze soaked in a $0.2 \%(\mathrm{v} / \mathrm{v})$ BAC (Aldrich, Milwaukee, Wis.) solution for $30 \mathrm{~min}$, or in $0.9 \%$ saline for the controls ${ }^{10}$. During this period, the gauze was soaked at 10-min intervals with a volume of about $2 \mathrm{ml}$ per esophagus. After treatment the abdominal surface of the esophagus was thoroughly flushed with $0.9 \%$ saline and the abdomen was closed. After surgery, animals were allowed to recover in individual plastic cages under controlled temperature.

\section{Radiographic study of the esophagus}

Three months after surgery, BAC-treated animals were submitted to radiological examination of the esophagus as described ${ }^{6}$ in order to confirm the appearance of megaesophagus. After the radiographic study, only animals that presented megaesophagus (ME) were selected to form groups B and BD of the experiment.
The animals were then divided into four groups: $C(n=8)$ - control group; B ( $n=8)$ - with ME; D ( $n=15)$ - with DEN and $\mathrm{BD}(\mathrm{n}=15)$ with ME plus DEN.

\section{Application of the diethylnitrosamine (DEN)}

Groups D and BD received DEN in drinking water at the dose of $4 \mathrm{mg} / \mathrm{kg} /$ day over a period of 30 days $^{11}$. The mean water intake by the animals was established at $30 \mathrm{ml} /$ day each animal. At the end of application of the carcinogen, the animals received an ad libitum diet for 12 weeks.

\section{Animal sacrifice}

At the end of 12 weeks after carcinogen application, the rats were sacrificed by excess ether inhalation. The esophagi were carefully isolated in one piece from the upper portion to the stomach at the pyloric sphincter level. The entire esophagus plus a small segment of the stomach near the cardia was removed from each animal. This stomach segment was used to locate the site of BAC or saline solution application. The esophagus was opened, stretched out and fixed with pins on a corkboard, immersed in $4 \%$ buffered formaldehyde for 12 $\mathrm{h}$ and stored in $70 \%$ ethanol. Fragments of about $2 \mathrm{~cm}$ from the terminal esophagus were embedded in paraffin, and $5 \mu$ m-thick longitudinal sections were cut and stained with hematoxylin and eosin for histopathology and for morphometric examination of the epithelium and muscle layer.

\section{Histopathology and morphometry of the esophagus}

Histological slices were submitted to morphometric analysis of the esophageal epithelium using a semiautomatic system of image analysis (MINI-MOP) in which the slice images were projected with a light camera and their contours captured with a digital board and fed into a computer. The surface area of the epithelium was then measured in its basal, intermediate and superficial layers. The results were expressed as mean area $\left(\mathrm{mm}^{2}\right)$ per group.

\section{PCNA-Labeling Index (PCNA-LI)}

To estimate esophageal cell proliferation in all animals from both groups, thin slices ( $4 \mathrm{~mm}$ ) from paraffin-embedded esophagi were immunostained with PCNA (PCNA/ Novocastra) as described ${ }^{9}$. A total of 2500 to 3500 nuclei were counted in the basal area of each esophagus. The PCNA-labelling index (PCNA-LI) was expressed as the ratio of positively stained nuclei to total nuclei counted.

\section{Statistical analysis}

Statistical analysis was performed by ANOVA. A probability of $p<0.05$ was considered to be statistically significant. The results were expressed as mean \pm SEM.

\section{Results}

All animals remained in good health and none showed clinical signs of nutritional deficiency during the experimental period. The esophageal diameter determined 
by radiography was $6.7 \pm 0.8 \mathrm{~mm}$ in groups $\mathrm{B}$ and $\mathrm{BD}$ (all BAC-treated animals) and $3.4 \pm 0.2 \mathrm{~mm}$ in groups $\mathrm{C}$ and D (animals that were not treated with BAC). On the basis of this difference between the esophageal diameters $(p=0.032)$, the animals from the groups $\mathrm{B}$ and $\mathrm{BD}$ were considered to have megaesophagus. "In the macroscopic analysis of group D, which received DEN, nine animals presented a normal esophageal epithelium and five showed a discrete thickening of the epithelium."In one animal, there was a small circular lesion, slightly high, sessile and brown colored. In group $\mathrm{BD}$, treated with DEN plus BAC, seven animals showed a normal esophageal epithelium and four presented a strong thickness and deepening of the natural surface sulci. Discrete irregular and diffuse nodulation areas were observed in three animals. One of the animals presented a lesion of approximately $1 \mathrm{~mm}$, high, circular and white, with irregular margins and an erosive aspect. Dysplasia was diagnosed in four animals by further histopathological analysis. No neoplasms were observed. Morphometric analysis showed an increase in epithelial thickness in the animals of this group when compared to the others, mainly due to basal layer hyperplasia, besides an increase in the keratin of the superficial layer (Figure1). The PCNA-LIs of the basal layer was significantly higher in the BD group compared to the other groups (Figure 2). However, no significant difference in PCNA-LIs was observed between groups $\mathrm{C}, \mathrm{D}$ and $\mathrm{B}$.

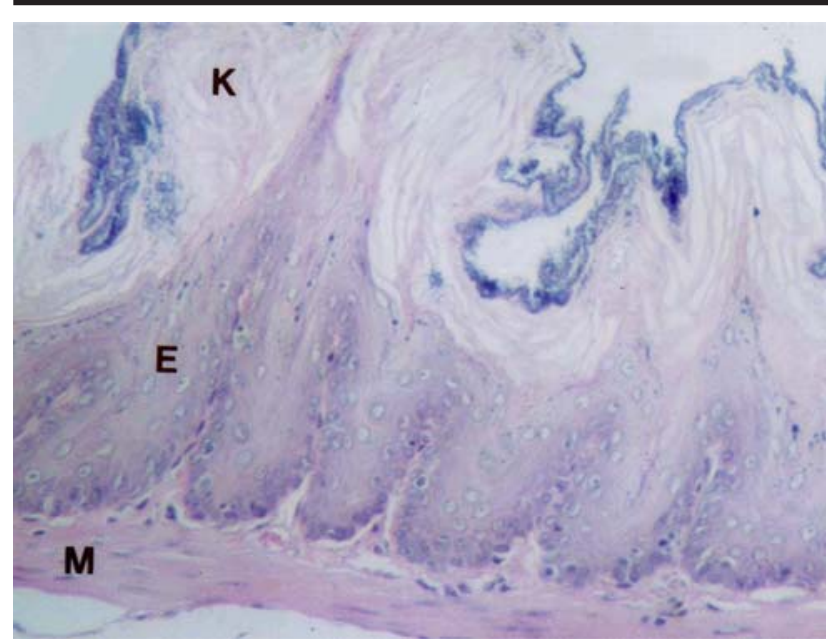

FIGURE 1 - Photomicrograph of the esophageal mucosa stained with $\mathrm{H} \& \mathrm{E}$ from benzalkonium choride (BAC) treated animal which receveid diethylnitrosamine (DEN) in drinking water (group BD) (100X). Note the increase in epithelial thickness, mainly due to basal layer hyperplasia $(\mathrm{p}<0.05)$, besides an increase in the keratin of the superficial layer. $\mathrm{M}=$ muscle layer; $\mathrm{E}$ =epithelium; $\mathrm{K}=$ keratin of the superficial layer.

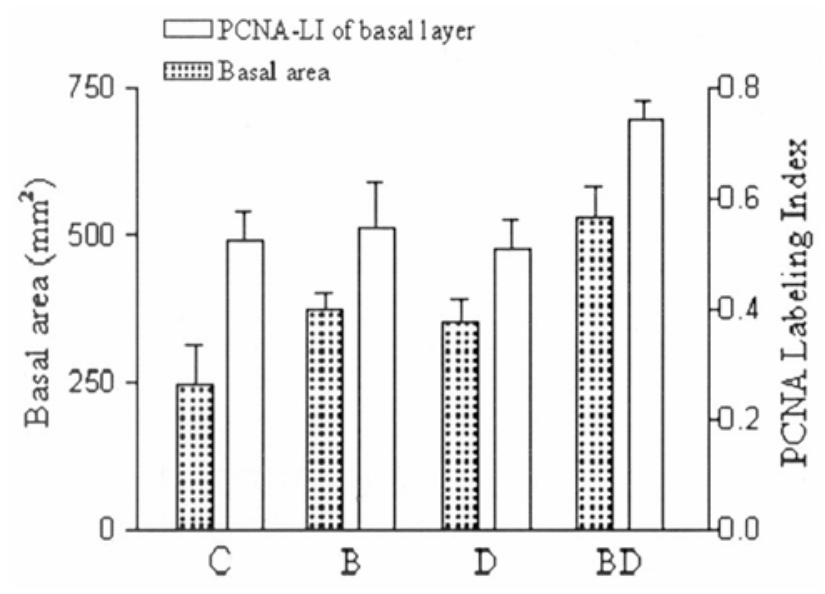

FIGURE 2 - Basal area and PCNA-labeling index (PCNA-LI) of the basal layer of the esophageal epithelium from control (C) and denervated (B) groups and from groups treated with diethylnitrosamine (DEN) (D) and denernated plus DEN (BD). There was an increase of the basal area and PCNA-LI of the epithelium in animals of group BD compared with the other groups $(\mathrm{p}<0.05)$.

\section{Discussion}

Achalasia and ME can be experimentally obtained in rats by topical application of benzalkonium choride (BAC) to the abdominal portion of the esophagus for ablation of the ganglion cells of the myenteric plexus ${ }^{6}$. In the present study was demonstrated that experimental achalasia was effective to increase the alterations considered preneoplastics induced by the ingestion of DEN in rats. The literature has been shown that quantitative histopathological analysis in terms of number of proliferating basal cell layers is of importance in determining the high-risk subjects for EC and evaluating the intervention results ${ }^{9}$. Thus, it is accepted that increases in cell proliferation index may play an important role in the pathogenesis of esophageal cancer in primary achalasia ${ }^{2,12,13}$. These changes were related to the increased risk of squamous cell carcinoma in these patients. In our study the BAC-treated animals showed increased epithelial thickness, mainly due to the basal layer hyperplasia, besides increased keratin in the superficial layer. Despite evidence from the studies performed in humans, the reasons for the association between achalasia and cancer of the esophagus remain poorly understood. Also the biomarkers for an increased risk in patients are poorly known, since it has been considered difficult to gather enough collective information in human patients to produce meaningful data. For this reason, the search for experimental models of the disease should be emphasized. As tumor multicentricity is occasionally observed in esophageal squamous cell carcinoma ${ }^{14}$, the field cancerization hypothesis may play a role in this case. We had previously discussed that at least in some cases, despite the fact that tumors probably arise from a single cell and are clonal populations, there needs to be some sort of co-operativity between cells for the neoplastic process to begin. In some cases the mutated clones, once established, spread through tissues before 
becoming overtly invasive. While there is substantial evidence in favour of independent origins of each tumour from a single mutated clone, there are instances in which such clones expand and remain cohesive, often involving a large area of tissue ${ }^{15}$. The experimental model described here may be useful for further studies on the mechanisms of the spread of preneoplastic lesions in the esophageal mucosa. The present findings indicate that in the early stage of esophageal carcinogenesis, both the PCNA labeled index and the area of the basal layer of the epithelium increase, indicating a hyperproliferative status of the cells that might be related to the cancer development.

\section{Conclusion}

Our data confirm in an experimental model the previous observation in humans of increased epithelial cell proliferation during the esophageal carcinogenic process in achalasia. Therefore, they may contribute to a better overall understanding of this association and eventually provide more information for the design of follow-up endoscopic studies in patients with achalasia. In conclusion, the new experimental model we describe opens extensive perspectives for further investigation in this area.

\section{References}

1. Balansky RM, Ganchev G, D’Agostini F, De Flora S. Effects of $\mathrm{N}$-acetylcysteine in an esophageal carcinogenesis model in rats treated with diethylnitrosamine and diethyldithiocarbamate. Int J Cancer. 2002;98: 493-7.

2. Bektas A, Yasa MH, Kuzu I, Dogan I, Unal S, Ormeci N. Flow cytometric DNA analysis, and immunohistochemical p53, PCNA and histopathologic study in primary achalasia: preliminary results. Hepatogastroenterology. 2001;48: 408-12.

3. Brucher BL, Stein HJ, Bartels H, Feussner H, Siewert JR. Achalasia and esophageal carcer: incidence, prevalence, and prognosis. World J Surg. 2001;25: 745-9.

4. Rocha A, Almeida H de O, Esper FE, Moraes DM de, Santos EP dos, Teixeira V de PA. Associação entre megaesôfago e carcinoma de esôfago. Rev Soc Bras Med Trop. 1983;16: 94-7.

5. Zucoloto S, Rezende JM de. Mucosal alterations in human chronic chagasic esophagopathy. Digestion. 1990;47: 138-42.
6. Febrônio LH, Britto-Garcia S, Oliveira JS de, Zucoloto S. Megaesophagus in rats. Res Exp Med. 1997;197: 109-15.

7. Aze Y, Toyoda K, Furukawa F, Mitsumori K, Takahashi M. Enhancing effect of ethanol on esophageal tumor development in rats by initiation of diethylnitrosamine. Carcinogenesis. 1993;14: 37-40.

8. Miyachi K, Fritzler MJ, Tan EM. Autoantibody to a nuclear antigen in proliferating cells. J Immunol. 1978;121: 2228-34.

9. Kuwano H, Saeki H, Kawaguchi H, Sonoda K, Kitamura K, Nakashima H, Toh Y, Sugimachi K. Proliferative activity of cancer cells in front and center areas of carcinoma in situ and invasive sites of esophageal squamous-cell carcinoma. Int J Cancer. 1998;78:149-52.

10. Luck MS, Dahl JL, Boyeson MG, Bass P. Neuroplasticity in the smooth muscle of the myenterically and extrinsically denervated rat jejunum. Cell Tissue Res. 1993;271: 363-74.

11. Ghaisas S, Saranathi D, Deo MG. ICRC mouse with congenital megaesophagus as a model to study esophageal tumorigenesis. Carcinogenesis. 1989;10: 1847-54.

12. Chino O, Kijima H, Shimada H, Nishi T, Tanaka H, Oshiba G, Kise Y, Kajiwara H, Tsuchida T, Tanaka M, Tajima T, Makuuchi H. Clinicophatological studies of esophageal carcinoma in achalasia: analyses of carcinogenesis using histological and immunohistochemical procedures. Anticancer Res. 2000;20: 3717-22.

13. Lehman MB, Clark SB, Ormsby AH, Rice TW, Richter JE, Goldblum JR. Squamous mucosal alterations in esophagectomy specimens from patients with end-stage achalasia. Am J Surg Pathol. 2001;11: 1413-8.

14. Fujiki T, Haraoka S, Yoshioka S, Ohshima K, IwashitaA, Kikuchi M. p53 Gene mutation and genetic instability in superficial multifocal esophageal squamous cell carcinoma. Int J Oncol. 2002;20: 669-79.

15. Garcia SB, Park HS, Novelli M, Wright NA. Field cancerization, clonality, and epithelial stem cells: the spread of mutated clones in epithelial sheets. J Pathol. 1999;187: 61-81.

\section{Acknowledgments}

The authors thank Mrs. Elettra Greene for revising the English text, and Mrs. L. M. Kawasse, Mrs M. A. O. Destido, M. H. L. N. Gomes, D. L. C. Simões, R. O. Lopes for technical support.

\author{
Correspondence: \\ Sérgio Britto Garcia \\ Ribeirão Preto Medical School, University of São Paulo \\ Department of Pathology \\ Av. Bandeirantes, 3900 \\ 14049-900 Ribeirão Preto - São Paulo Brazil \\ Phone: (55 16)602-3180 \\ Fax:(5516)602-1068 \\ sbgarcia@fmrp.usp.br
}

Conflict of interest: none Financial source: FAPESP

Received: May 18, 2005

Review: June 21, 2005

Accepted: July 24, 2005

\footnotetext{
How to cite this article:

Vespúcio MVO, Paschoal RM, Zucoloto S, Garcia FRB, Dalio MB, Soares EG, Garcia SB. A new experimental model to study preneoplastic lesions in achalasia of the esophagus. Acta Cir Bras. [serial on the Internet] 2005 Nov-Dec;20(6). Available from URL: http://www.scielo.br/acb.
} 